\title{
Public libraries marketing to teens: a study of two New Zealand libraries
}

\author{
by
}

\section{Helen Frances Biggs}

Submitted to the School of Information Management,

Victoria University of Wellington

in partial fulfilment of the requirements for the degree of

Master of Library and Information Studies 


\section{Acknowledgements}

Firstly, I'd like to thank my supervisor, Dr Philip Calvert, for the support and guidance he has given me throughout the year. His knowledge and interest in the topic was a valuable asset. I'd also like to thank the two participating libraries, and the individual staff members who agreed to take part in the interviews - they were hugely enthusiastic and helpful.

I'd like to acknowledge both my colleagues at Unitec Library and my personal friends who gave me continual encouragement and advice, and whose many kind words helped me through some sharp learning curves.

Finally, thanks and love to my parents, who not only drove me to interviews, doublechecked my grammar, made me a few thousand cups of tea and acted as living dictionaries, but who were my rock from go to whoa. I couldn't have done it without either of them. 


\section{Contents}

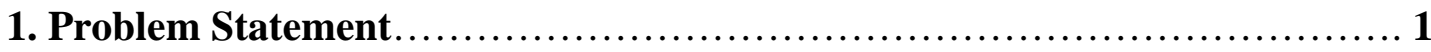

1.1 Rationale for the study........................................... 1

1.2 Definition of key terms ......................................... 2

1.3 Problem statement................................................. 2

1.4 Research questions............................................. 3

1.5 Theoretical framework........................................... 4

2. Literature review...................................................... 5

3. Significance of study $_{\ldots \ldots \ldots \ldots \ldots \ldots \ldots \ldots \ldots \ldots \ldots \ldots \ldots \ldots \ldots \ldots \ldots \ldots \ldots \ldots \ldots \ldots \ldots \ldots \ldots \ldots \ldots}$

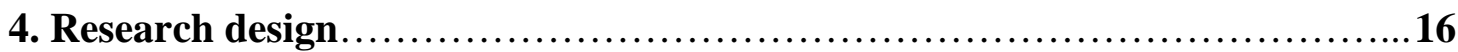

4.1 Research paradigm............................................... 16

4.2 Research methodology ............................................ 17

4.3 Research methods............................................. 17

4.3.1 Sampling .................................................... 19

4.3.2 Interview questions......................................... 19

4.4 Data analysis techniques........................................ 21

4.4 .1 Interview analysis......................................... 21

4.4.2 Document analysis........................................ 21

4.5 Ethical considerations............................................. 22

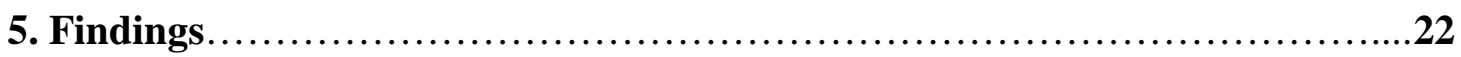

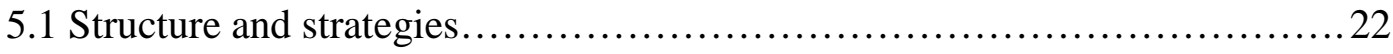

5.2 Market segmentation................................................ 25

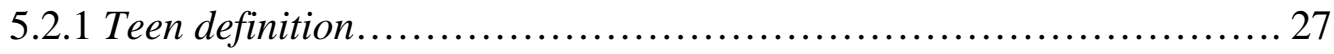




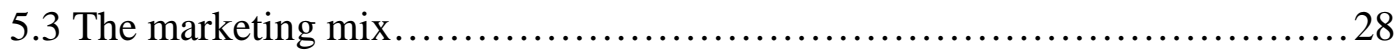

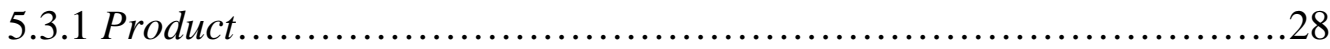

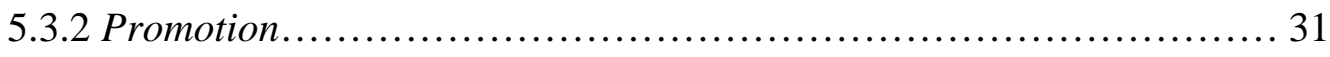

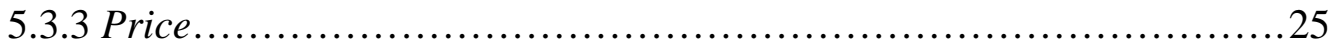

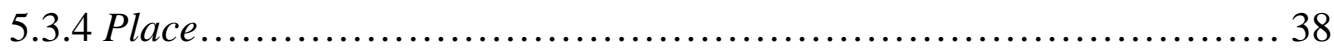

5.4 Evaluation...................................................... 41

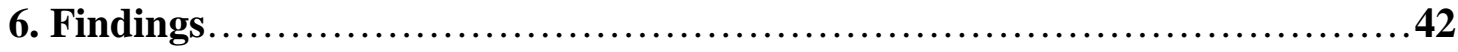

7. Conclusions........................................................55

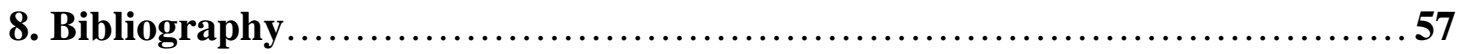

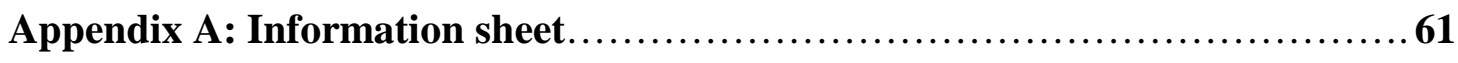

Appendix B: Consent form.............................................. 62

Appendix C: Emails...............................................63 


\begin{abstract}
Marketing in libraries has been widely discussed in literature, but is often limited to either prescriptive writing on the application of marketing theory to libraries, or descriptions of marketing at individual libraries with little theoretical basis. The purpose of this research was to compare the teen marketing practiced by public libraries with library marketing theory, and to discover whether the application of theory is a conscious decision by libraries. Staff were interviewed at two New Zealand public library networks to discover whether they considered marketing targeting theory and the marketing mix when marketing to teens. It was found that while both library networks did do some formal teen marketing, the majority of marketing was conducted more informally by individual community libraries. Libraries struggled in particular with defining their teen users, and the marketing mix was dealt with in an ad hoc manner. Overall, library marketing was more tactical than strategic.
\end{abstract}

Keywords: public libraries, teenagers, segmentation, marketing mix, marketing strategies 


\section{Problem Statement}

\subsection{Rationale for the study}

When the concept of marketing was first applied to public libraries, it was a somewhat controversial idea. Marketing was seen to be a capitalistic, profit-driven, and goods-based discipline not commonly associated with public libraries. However, the development of services-marketing theory as well as theories of public-interest goods and services and not-for-profit organisations have gradually made the idea of marketing more palatable for public libraries - as a way of informing their patrons of the wide range of services they offer, building relationships with their patrons, and a means of showing themselves to be useful and relevant institutions.

Some applications of marketing theory in libraries are obvious. Books are segmented to appeal to particular markets - into children's, teens', and adults' areas, for example. In some libraries, such as the Auckland City Libraries, fiction is even divided into genres in order to appeal to those who seek a certain type of novel. However, without speaking to library staff and management, and consulting relevant documentation it is impossible to tell whether such acts have been done as a result of a formal marketing plan, or whether they have happened organically. It is also difficult to surmise what other aspects of marketing theory have been used and considered.

It is a common-held belief that public libraries find teenagers to be their most disinterested group, as discussed in Section (2). Teens are a group whose interest is hard to attract, and just as difficult to retain. Public libraries have used, and still use, a range of 
services to try and attract teenagers, including loaning DVDs, console games and comics, and designing areas which are just for teens. Simply creating these services is not enough, however; they must also be actively marketed to teens.

\subsection{Definition of key terms}

Marketing: "...a social and managerial process by which individuals and groups obtain what they need and want through creating and exchanging products and value(s) with others." (Owens, 2003a, p. 1)

Public libraries: Libraries which "exist to provide the residents of their community with access to the record of human thought and achievement, for the purposes of information, education, recreation and culture" (Chamberlain, Chamberlain, \& Cabral, 2007, p. v)

Teenagers and/or teens: There is no consensus among libraries of who exactly counts as a teenager - the age range of the group has been defined as broadly as 10 to 19 years (Andersen, 2007)- but in setting up the framework for this research, and given the New Zealand context, high school-aged young people of 12 years to 18 years were assumed to be teens. The definition of teenager in the context of the two participating libraries will be revisited in Section 5.2.1.

\section{$\underline{1.3 \text { Problem statement }}$}

There are many opinions, often based on anecdotal evidence, on what attracts and repels teens to and from libraries, and within these differing opinions several main themes seem 
to recur. These themes and the literature at large will be further explored in Section 2. What becomes apparent from the literature is that public libraries should promote themselves as a place which can fulfil their role as defined by Chamberlain, Chamberlain and Cabral by answering teens' information, educational, recreational and cultural needs; and that these libraries need to develop viable, formal, marketing strategies to do so.

Although the concept of marketing in libraries has been a contentious one, most librarians now seem to acknowledge its potential and importance. However, there is still relatively little research into which marketing strategies are the most effective for libraries promoting themselves to teens, and very minimal information on how this might apply in a New Zealand context. Although the concept of marketing now has less of a stigma attached to it in the library environment, it is not apparent how many, and to what extent, libraries actively or unconsciously apply marketing theory to their own attempts at marketing.

\section{$\underline{1.4 \text { Research questions }}$}

Main research question:

How consistent with marketing theory is New Zealand public libraries' marketing to teens?

\section{Sub-questions:}

To what extent is libraries' marketing organic and informal, as opposed to structured and formal? 
How is marketing strategy developed by public libraries?

How does marketing theory influence libraries' marketing policy and strategies?

\subsection{Theoretical framework}

This research project was framed around marketing theory in order to relate the marketing conducted by public libraries to the dominant relevant theory. This was not a new or innovative approach to the subject - the theory developed for marketing has already been considered in relation to information management, even specifically to public libraries, in previous research investigating similar topics.

Within marketing theory, there are two models of particular importance for this research project. These are consumer targeting, and the marketing mix. Consumer targeting involves understanding consumers' needs and wants in order to satisfy them, and involves three steps: market segmentation, market targeting, and market positioning. Market segmentation involves grouping (or segmenting) consumers based on their needs and wants. The next two steps involve deciding which segment of the market to appeal to, and deciding how a product or service is going to appeal to that segment relative to competitors.

The marketing mix is a marketing model which has had a long development; it describes the controllable elements used to market a good or a service to its target consumers. The most common incarnation of this theory today is the " 4 P's", first proposed by E. Jerome McCarthy in 1960, which asserts that the basic 'recipe' for a marketing mix contains the 
elements of product, price, place, and promotion (Kotler, Brown, Adam, Burton, \& Armstrong, 2006).

Overall, marketing strategy theory provided a clear framework on how public libraries should be, or could be, forming their marketing strategies for teens. That these theories and models have already been studied in information management literature shows that the framework they offer was a valid one for this research project.

\section{Literature Review}

Much of the library and information services (LIS) literature in the area of marketing is still prescriptive, or limited to case studies of individual libraries. This does not mean that it is not useful, but simply that the lack of wide-scale research into this area means a lack of empirical evidence into why, how, and whether marketing works for public libraries marketing to teens. There is also a need for research which is specific to the New Zealand context. However, this review will draw out what themes there are in the literature, focussing particularly around the marketing mix and the relationship between libraries and teens.

Although marketing theory has existed for some time, it was not until the 1980's that libraries began to consider how to use marketing theory themselves (Coleman, 1984). Perhaps it is as a result of this that libraries have been seen to be behind comparable organisations in their approach to marketing (Doherty, Saker, \& Smith, 1998). Another reason that has often been offered is that librarians have a negative attitude towards 
marketing, although, recent research has shown that this is not the case; librarians are overall positive about marketing (Aharony, 2009; Nkanga, 2002). Staff at all levels of a library can impact on how successfully marketing is executed, meaning that any difference in attitude or opinion between strategic and operational staff will influence the implementation of marketing strategies (Harrison \& Shaw, 2004). Librarians tend to lack any formal training in marketing (Shontz, Parker, \& Parker, 2004), which may be a possible reason for some of the problems that libraries have with marketing.

One issue with libraries' marketing that emerges in earlier literature is that promotion is often the only ' $\mathrm{P}$ ' that is discussed in detail, with a lack of lateral thinking shown in researchers' inability to address price, product and place and relate them to libraries; examples of libraries using marketing often only includes promotional activities (Baldock, 1993). One survey shows that promotion is in most cases the only form of marketing that is carried out by libraries (Doherty, Saker, \& Smith, 1995). This sole concentration on promotion means that other opportunities for marketing are lost. However, more recently, the theme of needing to look beyond promotion has emerged, with commentators arguing that a promotion-only focus "misses the point" of the steps of segmentation and targeting.

One form of promotion gaining popularity in libraries is branding, as evidenced by a recent study in the UK which found that branding is particularly used by libraries wishing to dispel negative images of libraries and librarians (Hood \& Henderson, 2005). In New Zealand, branding has been used to differentiate services provided to children or teens 
(examples include Kids Zone and Hyper Youth) from those provided to adults (Chew, 2007). However, despite these brands existing they are often not promoted outside of library websites, suggesting that New Zealand libraries have yet to recognise the real concept and rewards of branding.

On the subject of what specific methods libraries can use to promote themselves to teens, there is a suggestion that the concept of 'Libraries 2.0' should be pushed further, introducing the idea of 'Teen Services 2.0'. Importantly, 'Teen Services 2.0' does not focus solely on virtual services, but still allows for the existence of the physical side of libraries (Bolan, Canada, \& Cullin, 2007). Many writers are not so broad in their focus, embracing Web 2.0 as the perfect method of attracting teens, without considering other options. Another increasing promotional activity is "booktalking", wherein libraries go to local high schools and talk about various books to try and capture teens' interest in them (Carpenter \& Caton, 2008; Mahood, 2004). The concept of public libraries and school libraries supporting each other's attempts to get teens into libraries is not uncommon, and there are also examples of libraries partnering with organisations such as hospitals (Ruhlmann, 2010) in order to take their library services to children and teens who can not come to libraries themselves. This may be seen as more of a goodwill gesture, but this is an opportunity for libraries to promote a positive image of themselves to the public. Working with outside organisations can also help public libraries cultivate closer ties with their communities, and create new services at a lower cost than it would be to develop them alone (Bourke, 2007). 
Product is a concept that is potentially confusing when applied to libraries. There is a tendency to dwell solely on lending and reference services, perhaps because the services that libraries provide are myriad and therefore difficult to encompass in a concise definition. The idea that a "product or service is anything that the library or information service is offering, or could offer, that would be of benefit to users and potential users" (de Saez, 2002, p. 57) seems to best encompass this, even if it lacks in differentiation between products and services. This lends itself to another problem, however; the literature mostly deals with the idea of marketing the library as a whole, rather than one particular service at a time. This means that libraries often need to develop their own strategies for marketing a particular service - such as James Madison University's "virtual library" (Fagan, 2009). Another problem is that of services which are available for one particular group, such as graphic novels for teens, not being marketed beyond word-of-mouth (Snowball, 2007).

Price has a wide range of definitions in the literature. Traditionally, price describes the amount of money paid by the customer for the product. However, historically libraries user fees have been minimal or non-existent, which makes price difficult to apply. In monetary terms, price has been defined as the cost to the library of supplying goods, rather than its patrons (Owens, 2003b). This approach is relevant when considering that library patrons only pay for services indirectly, and that public libraries need to justify their financial decisions to their council and other stakeholders. However, this ignores the fact that as part of the marketing mix, the cost of library services influences the attracting or discouraging of patrons. Alternative definitions of price are therefore needed, such as 
"what a trip to the library is worth to users in terms of time to get to the library, time to learn the systems, or time to use the services.” (Rossiter, 2008, p. 16)

De Saez also offers the idea of opportunity cost as a 'price', and this is particularly relevant when dealing with teens. A case study conducted in a public library in Missouri suggested that, on the whole, teens do not have entirely negative feelings towards libraries; rather, they do not go to their public library because there are other activities they prefer (Cook, Parker, \& Pettijohn, 2005). Teens need to be able to feel that they are not giving up anything valuable by choosing to use their library.

Place has changed dramatically with the digital revolution. It no longer solely refers to the library building itself, but has grown to include library websites and other digital access points, which are particularly popular with children through to young adults (Kern, 2009). Whether this is finally changing patrons' and non-patrons' view of the library as a "moribund storehouse of outmoded information" (Van Slyck, 2001) is yet to be seen.

Place is particularly interesting when dealing with teens. One common thread that runs through much of the literature is the need for teenagers to have their own physical space in a library, with the suggestions that a well-designed space "will tell older teens that they are welcome in the library and even encouraged to stay" (Alessio, 2004, p. 87). While the library which has its own dance floor for teens is an extreme example; even the slightly more mundane libraries have anecdotal evidence of an increase in teen users since redesigning teen space. Importantly, library and teen culture need to intersect within a 
teen space (Walter \& Meyers, 2003); teens need to recognise that is a place that belongs to them, but at the same time it must still operate as part of the library.

In the New Zealand context, Rowe picks up on this idea of designating a space particularly for teens and children, considering three different aspects of the public library's role, and how each one can be designed to appeal to teens - the library as a leisure reading and activities centre, a formal education support centre, and a community focal point (2002). Unfortunately, this piece concentrates on what facilities can be designed for a new building, not a pre-existing one. For many public libraries in New Zealand, moving to a new building would be ideal, but is not practical given financial constraints. There are still other options, however - while constructing new physical space may be unfeasible, there is also the opportunity to construct entire virtual libraries just for teens (Delgado-Gomez, 2002).

On a smaller scale, websites are often considered as potential marketing tools for drawing in teens, with the added advantage that teen-specific material can be added to already existing websites. Braun sees interactive, rather than static, websites as preferable, and suggests that the viral marketing campaigns which have been successfully used in other industries could be used by libraries. The idea of libraries using social networking, of giving information "in the places teens can already be found" (Braun, 2009, p. 510) and going to where teens are rather than expecting teens to come to libraries, is picked up several times in the literature, with the added caution that "given [teens'] welldocumented fickleness, they will probably move along quickly to the next digital 
hangout." (Doyle, 2008, p. 505) If libraries are marketing to teens through social networking, it is important that they stay with current trends - there is no point investing time in a site which is no longer popular.

While the 4 P's were originally developed to apply only to marketing tangible goods, the so-called 'extended marketing mix' adds three more P's to the original four: people, physical evidence and process (Booms \& Bitner, 1981) which "distinguish features of service encounters" (Kotler et al., 2006, p. 106) ; however, these are seldom picked up on in LIS marketing literature. While these are arguably needed in order for patrons to perceive a high quality of service (Smith \& Saker, 1992) de Saez argues that these aspects, while important to consider, are in fact already included in the original 4 P's (2002). Other marketing/LIS theorists have devised their own extended marketing mixes, such as "the right product, in the right place, at the right price, with the right promotion, for the right person" (Roy, 2003) and positioning (Walters, 2004) but the same argument can be used against these, suggesting that the original 4 P's, when defined and used appropriately, are the best and only marketing mix libraries need consider.

Oddly - perhaps worryingly - one step which is missing from most of the literature is that of evaluation. This is hardly a revolutionary concept; the marketing model in Coleman's 1984 article includes evaluation as a key step. And yet few others include it in their prescriptive writings. Interestingly, those that do include evaluation, clearly see it as an important part of the marketing process. Weingand develops an extended marketing mix, dubbed 'the 6 Ps', which includes 'Postlude - the evaluation'. The idea that 
"evaluation is a tool for improving services" (Weingand, 1999, p. 146) is also picked up by Dubicki, who suggests that:

"Evaluations of the marketing plan process should be ongoing, not just at the end of the campaign. Marketing is always dynamic because customer needs and library services change, perhaps necessitating modifications to the marketing plan.” (Dubicki, 2007)

The study of the use of the extended marketing mix in New Zealand public libraries can be seen in Clayton's research into the marketing of web pages (Clayton, 2007). Web pages were broken down by each section of the extended marketing mix, and graded by a selection of relevant criteria. Clayton found that while New Zealand public libraries had a varied understanding of price and physical evidence, overall their marketing compared favourably to libraries in the US, the UK, and Australia. However, as these findings related solely to web pages it is unlikely that they can be applied universally to public libraries' marketing practices.

There are several problems when dealing with libraries targeting teens in particular. One of the problems apparent in the literature as a whole is a lack of clear definition of what constitutes a "teen", a word which is at times used interchangeably with "young adult". At other times, teens are grouped together with children under the category of "youth" or "youths". This arguably links to segmentation difficulties that libraries have; if a segment is poorly defined, or even undefined, it will be hard or even impossible to target. 
Anderson defines two groups, "older teens", aged sixteen to nineteen, and "tweens and young teens" (Andersen, 2004), aged fourteen and below, (Andersen, 2007) but also reiterates that as teens are in different stages of development they cannot be judged strictly by age.

However, this division into "older" and "younger" teens matches anecdotal evidence that suggests that marketing geared towards a general concept of "teenagers" may not actually interest teenagers of all ages, and that marketing should be directed towards more specific age groups (Tyle, 2008). Other evidence shows that girls and boys respond to libraries in different ways (Agosto, Paone, \& Ipock, 2007), which suggests that gender should be a factor in targeting specific groups of teens. Dimick goes even further, explaining that children and teens can and should be segmented - not only demographically, which takes into account age, gender and ethnicity, but psychographically as well, a category which looks at personality, interests and opinions, among other factors (1995).

Another problem with the targeting of markets by libraries which is non-specific to teens is the impact of external forces, particularly politics, when local government focuses all marketing on other groups such as ratepayers for political reasons (Kinnell \& MacDougall, 1992; Sutherland, 2002).

Finally, the existing relationship between teens and libraries needs to be examined. Much of the literature exploring this subject is concerned with the perceptions teens have of libraries, and the lack of understanding librarians - in particular, library management - 
have of teens (Snowball, 2008). A New Zealand study which looked at local young adult library services and the perceptions of both users and providers found that both groups saw staffing as a problematic area; young adults usually saw staff as rule enforcers, and found their experiences with them to be unpleasant (Owen, 1998). This view complements the idea that the library is closely associated with school, and therefore work, making it an unlikely place for teens to visit in their own free time (Corradini, 2006). Interestingly, this latter Italian study touches briefly on the fact that librarians have their own ideas of how teenagers view libraries - "young adults are frequently said to consider libraries as uninteresting and cold, solemn and rigid, boring and old-fashioned" (Corradini, 2006, p. 486) - and suggests that this is not always an accurate portrayal.

The previously mentioned digital revolution has not only changed the sense of place of the public library, but is also impacting its role. Already search engines like Google have changed the way that young adults are looking for information (Mi \& Nesta, 2006). Although this has not been coupled with a drop-off in library users, it does suggest that libraries need to consider alternative roles. While Rowe considers three such roles, and Cook, Parker and Pettijohn emphasize the need for libraries to become more involved in the social lives of teenagers, Jones goes a lot further, suggesting that libraries should be focusing on an overall strategy of youth development, "an approach toward youth that builds on their potential and helps counter the problems that may affect them" (Jones, 2002, p. 22). 
There is clearly a strong theoretical base for public library marketing; it is equally clear that public libraries understand the need to market to teens in order to catch their interest. What is less clear is how well public libraries actually grasp concepts such as the marketing mix and market segmentation, and how capable they are of applying the theory to practice. While there is much anecdotal evidence into what methods of marketing work, there are few studies covering whether these methods would work for all libraries, or whether they only work in the given contexts. However, it is evident that the 4 Ps can provide a strong basis for this research project - the literature has provided working definitions of product, promotion, price and place that can be applied to public libraries, and possibly built on further. Another issue which has not been dealt with conclusively is exactly why young people lose interest in the library during their teen years. Much of the literature seems to be based around assumptions that all teenagers behave in the same ways, with few researchers questioning these assumptions. What is needed is more research, comparing and contrasting the marketing done by different libraries, to see what ideas are effective, and what segments of the teen market they attract.

\section{Significance of study}

Firstly, the library networks selected for this research both serve a large proportion of the country's population, and offer library services to children, teens, and adults from a wide variety of ethnic and cultural backgrounds. In this way, their patrons very much serve as a microcosm of New Zealand society. By understanding, comparing and even critiquing their marketing models, and exploring their successes and failures in this area, other public libraries in New Zealand can learn from these examples. 
Secondly, as previously mentioned, there has been relatively little research done in this area in New Zealand. While this case study will only be focusing on two libraries' approaches to marketing, it is hoped that it will not only allow other public libraries to examine their approaches to marketing, but that other researchers will take an interest in the subject, so that more research, discussion and debate can be had over the place and importance of marketing public libraries' services to teens.

\section{Research design}

\section{$\underline{4.1 \text { Research paradigm }}$}

For this research project, an inductive approach was thought to be more appropriate than a deductive one as data needed to be gathered to support the design of a theory which satisfied the proposed research questions. From an epistemological perspective, interpretivism was a better position than positivism for answering the proposed research questions as it emphasises the need to study human actions through the interpretations of its actors. Ontologically constructivism, which "implies that social phenomena and categories are ... produced through social interaction” (Bryman, 2008, p. 19), allows that the outcomes of libraries' marketing strategies are influenced by both the staff involved in making and implementing them, as well as the patrons who react to them. This was clearly a good ontological approach for research which was examining the way marketing strategies are influenced by various actors. 


\section{$\underline{4.2}$ Research methodology}

The research questions for this research proposal, when coupled with the lack of previous research in this area, suggested a need for research which was in-depth. As at the time that the research was being conducted there was no information available on what marketing strategies were used by public libraries in New Zealand, it was impossible, for example, to present a closed list of such strategies to libraries and ask them to choose which one they used for teens. What was needed, was a method that could discover the reasons and explanations for the decisions made in marketing strategies by libraries, and the decisions behind how those strategies are applied in practice - qualitative methods. A qualitative approach was clearly the more appropriate one to use when conducting this research.

\section{$\underline{4.3 \text { Research methods }}$}

The overarching method chosen for this research concept was a case study, focussing on two public library networks in the North Island. While there was room within this topic to choose a sample size which consists of multiple public libraries - there are over 60 such organisations in New Zealand (Association of Public Library Managers Inc, 2010), carrying out in depth, qualitative research, among geographically distant libraries within the project's given timeframe was simply unachievable. While this case study would not have had the scope of a larger sample, it was considered to be the appropriate method to use in a research project that set out to "illuminate a decision or set of decisions: why they were taken, how they were implemented, and with what result.” (Yin, 1994, p. 21) 
In this case, this applied to the decisions made around marketing strategy at the two participating libraries.

Within the method of the case study, data collection occurred in two distinct ways, in order to allow triangulation to occur: interviewing, and using documents as a source of data. Interviewing took place in a semi-structured, face-to-face manner; documents incorporated promotional materials including - but not limited to - organisational websites, social networking sites, posters and brochures. Documents were analysed as both as examples of marketing activities and for clarification on some aspects of marketing that were unfamiliar to interviewees. Unfortunately, neither of the two libraries involved with the research were able to offer formal, written marketing strategies for analysis.

The reason for using a semi-structured interview was to allow flexibility both in the interviewer's questions and interviewee's responses while still maintaining a focus on the specific research topic, and to make sure the interviewer maintained control on the direction of the interview. While only one interviewee, a strategic staff member at Library A, had any formal marketing knowledge, strategic staff at both Libraries had some familiarity with ideas on libraries and marketing, through their own reading of library literature.

Using these methods did potentially open up this research for a certain amount of bias. Firstly, the researcher is a patron of one of the chosen libraries, and as such already had a 
relationship with the organisation. However, as the relationship is only that as a library user, and there were no personal connections with any of the interviewed staff, it can be argued that the potential for bias in this way was minimised. Secondly, there was the potential for censorship in terms of interviewed staff willingly skewing their answers in order to present their organisations in a positive light. It is to be hoped that by taking steps to keep the interviewees anonymous and not naming their libraries in the presentation of this report, they felt able to take part in their interviews in a free and frank manner.

\subsubsection{Sampling}

Purposive sampling, rather than random sampling, was used in order to only conduct interviews with the most relevant staff members, with five to six interviews taking place at each of the public libraries. Interviewees were chosen in consultation with senior staff at each library, again to pick staff members with roles pertinent to the research subject.

In this way, staff interviews were from a range of levels, and included operational staff such as librarians and library assistants, and staff with more of strategic roles, such as service managers and co-ordinators. All staff interviewed had roles which meant they were formally involved with teens or in library marketing, and in some cases both.

\subsubsection{Interview questions}

The following questions were asked/covered in interviews. 
- Describe your role at the library. How much of your role is about setting strategy, policy, or process? How much of your role is operational?

- Thinking of the people who use your library, tell me about five different groups of people. Do they use the library in different ways? Which of these groups are priorities for the library?

- How does the library communicate with these five groups of people? Are there opportunities for these people to communicate with the library?

- Thinking of the age range $12-18$, describe how these patrons use the library. How does their use compare to other age groups?

- Thinking of the age range $12-18$, describe how these patrons' use of the library is encouraged.

- What physical place in the library is there that has been adopted by, or adapted for, these patrons?

- Which of the library's online content has been designed for these patrons? How well is it used?

- In order to use the library and its services, what are these patrons giving up?

- Which of the library's services were designed for these patrons? Which other services do they use?

- Do you have any formal marketing knowledge, or have you read marketing theory?

- Does the library have a formal marketing strategy? Does it specifically address teens?

- What is the library's formal marketing strategy for teens? 
- Do you measure the results of this strategy (if there is one)? What results have you achieved?

\subsection{Data analysis techniques}

\subsubsection{Interview analysis}

Grounded theory, although not chosen as the overarching method for this research concept, nonetheless provided a practical framework for the analysis of the gathered qualitative data, particularly in the coding of information that had been collected. Following Bryman, there are four key "tools" offered in the grounded theory framework: theoretical sampling, coding, theoretical saturation, and constant comparison (2008). As mentioned in Section 4.3.1, purposive sampling, not theoretical sampling, was used in this research. Some coding, however, was used, with data being coded without using "preconceived standardized codes" (Bryman, 2008, p. 542), in order to identify and explore the concepts, themes and patterns which arose from the documents and interviews. To do this, interviews were recorded when they took place, and transcribed as soon as possible afterwards. Notes were also taken during the interviews in order to capture as much information as possible.

\subsubsection{Document analysis}

Collected documents were analysed in the same way as the interviews, with a groundedtheory approach of coding and comparison. 


\subsection{Ethical considerations}

Under the guidelines laid down in Victoria University of Wellington's Human Ethics Policy, human ethics approval was applied for and granted before this research was carried out, as it involved human subjects, as well as potentially involving commercially sensitive information supplied in confidence. Informed consent was acquired from all interviewees taking part in this research; the information sheet and consent form given to every participant can be found in the Appendix. Subjects' privacy has been protected as far as it is possible to do so.

As this research was carried out as a case study, looking in depth at particular libraries' marketing strategies, it was considered to be of particular importance to make sure that authorisation was fully granted by the selected libraries to access their employees and spend time in their buildings, and to have clear guidelines as to what information they are prepared to let be used for the case study. Therefore, the Head Librarians (or equivalent positions) at both libraries were contacted for permission before research began, and written agreement was obtained from both libraries before individual staff members were approached for interviews.

\section{Findings}

\subsection{Structure and strategies}

Both library networks studied for this research are library networks rather than individual libraries; that is, each is a group of community or branch libraries run under a single regional or city council. For clarity, the library networks will be referred to as Library A 
and Library B; the individual community libraries within these networks will be denoted as such.

Both Libraries have a similar, centralised management structure that specify organisation-wide, core services but allow community libraries to develop some services for their own communities. These local initiatives include small-scale events such as book clubs and movie nights.

The Libraries differ somewhat in their approaches to both teens and marketing. Library A's marketing is developed in-house, by a team that includes a marketing advisor and a graphic designer; Library B do not have their own marketing team, but work closely with their council's marketing team. Neither Library has a strategy which specifically addresses marketing to teens, although interestingly operational staff at both Libraries assumed that there was one. At the time of these interviews, Library A had recently committed to developing such a strategy, as one strategic staff member explained:

"This year, in our business focus, we do have a tactic around developing a strategy for increasing teens' engagement. It should be a strategy that acknowledges that we already develop quite a bit of service to teens, that teens use our services to some degree. So the strategy might be about identifying some gaps where we can do some more, rather than starting from scratch." 
Library B has no current formal marketing strategy. A major structural change to the library is imminent, and this has meant that recent library plans have been what one strategic staff member terms as tactical, rather than strategic, focussed on the short-term, rather than the long-term. However, this does not explain the longer-term absence of a strategic plan, and is in contrast to Library A, which will be facing a similar structural change at the same time as Library B.

In terms of staff structure and teens, the two Libraries once again have similar approaches. There are top-level strategic staff at both Libraries who oversee both children and teens - sometimes referred to together as youth - and at community libraries, one or two librarians or library assistants will take on the role of focussing particularly on teens. What exactly this 'focus' involves does appear to vary greatly between individual community libraries. Library B community libraries encourage regular meetings of teenfocussed staff, and will also "buddy-up" librarians who serve teens with library-assistants in the same role "So they can learn from each other as well". Library B is also moving towards "having teen librarians so that it's a professional position, and it's part of their job description when they apply for it that they're going to be a teen librarian." At Library A, there are fewer opportunities for teen librarians and library assistants to interact, although several interviewees suggested that with the new strategic focus on teens, this may change. 


\subsection{Market segmentation}

Both Library A and Library B have segmented their markets in a basic and obvious manner. Both libraries divide their users into three patron 'types', based on age children, aged up to 12 years; teens, aged 13 to 17 years; and adults, aged 18 years and over. These patron types are treated differently in terms of library policies around borrowing and circulation.

Another form of very evident market segmentation happens as a result of the spread of each Library's community libraries across different suburbs, which support differing populations in terms of socio-economic status, population age and ethnicities. Both Libraries emphasised the need for community libraries to "reflect their communities", or to customise and produce services which are wanted by their own patrons, but might not be applicable to other community libraries. An example of this is holding specific nonEnglish or Māori language fiction collections.

At Library B, staff members commonly referred to the differences between two areas of their region, a divide caused by the socio-economic disparities between the two areas. The most discussed differences were in terms of circulation - "in particular it's our [area] branches [which are] generally where the biggest readers come from, while others - I don't think that they're not readers, I think that often they read in house.... And they have lower circulation stats than other areas" - and computer usage, where lower socio-economic areas relied more heavily on community libraries for computer and 
internet use. Library A also saw similar disparities, although its region's socio-economic gaps were not so neatly geographically divided.

Beyond this, the segmentation suggested by staff members varied at both libraries. One segment identified with some consistency at Library A was "mothers and babies". This was also the segment whom strategic staff identified as the one for which Library A had most recently spent time developing and promoting services, which had seen success to the point that they had become embedded in the community libraries which ran them. This may explain why this segment was consistently recognised by staff.

Apart from mothers and babies, there was no strong pattern as to either the criteria for differentiating segments, or how they were identified. Although groups such as "children" and "the elderly" are clearly marked by their ages - although a specific age for either was seldom given - some staff preferred to identify groups by which library products and services they used. Strategic staff members at Library A also took the approach of defining groups by their actions rather than demographics or psychographics, listing the six "service lines" that Library A has developed. “...regardless of their demographics, they come in to read and borrow, for learning programmes, for officephotocopying and that sort of stuff, research and information, as a community space and for events and exhibitions".

Libraries B followed a similar pattern. Youth - described as young people aged from 0 years to 25 years - was identified by strategic staff as being an important market segment, 
due to the large population of young people living in their region, and operational staff were able to identify several segments within this category. Most identified preschoolers, children and teens as separate groups, and named elderly patrons as an individual group as well.

\subsubsection{Teen definition}

While the definition of a 'teen' had been set by the researcher to be 12 - 18 years old, the age that most young people attend high school, it quickly became apparent that many of the interviewees themselves differed from this definition; for some this was because they had their own idea of what a 'teen' was (“it's more like 13 to 15"), while others had no clear classification of the term, but felt that an age range was too restrictive: "The difference between a 13 year old and a 19 year old is light years. You've got a child at one end and a responsible adult at the other." "...there just seems to be this unnecessary, arbitrary demographics."

However, there were some aspects of 'teenager' that were consistently identified by interviewees as marking teens as separate from other groups. One was the dependent status of teens; most saw some teens, typically older teens, as craving independence, but still legally minors and reliant on their parent or guardian, while other teens were comfortable still relying on their parents or guardians. This meant that library staff needed to consider parents in dealing with teens, while still treating teens as individuals, in a non-condescending manner - "it's a balancing act". One operational staff member at Library A used the example of her book group - "if I introduce any kind of content that is 
hard to deal with, like suicide or sex or something, that I just make sure that it's something that I would be willing to defend or talk about with a parent, or with the kids. ...'Cos it is a responsibility and you can't just chuck stuff at them."

\subsection{The Marketing Mix}

\subsubsection{Product}

At both Libraries, products can be divided into two types: organisation-wide products, which are usually organised and run centrally, and which include core library services; and community-level products, which are generally developed by community libraries for their own localities.

The core service identified by many of the interviewed staff at both Libraries as still being the most important service provided by the library, is lending. As mentioned previously, 'teens' are a specific patron type, and all community libraries have their own, teen collection. At both Libraries, staff members were apt to divide teen collections into three groups, echoing how the collections are physically arranged on the shelves fiction, non-fiction, and graphic novels, this last division including manga and Western comics. The teen fiction collection is floated at both Libraries.

At Library A, staff highlighted the recent addition of study guides to their non-fiction teen collections; at both Libraries, "the non-fiction for youth is meant to mirror their life, it's to do with their life and lifestyle and things like that" and there is an emphasis away from buying text books or other material which should be provided by high school. 
However, when it came to study guides, Library A realized that "some families have been able to afford study guides and others haven't. There's quite a social equity gap there for young people who are studying."

The acquisition of graphic novels was also a talking point at Library A, where an online request form has seen a large uptake by teens, to the point where "our teen purchaser doesn't actually have to keep up-to-date with any manga title, because the kids do it for her." Library B has also seen similar uptake for the same service, to the point where almost $50 \%$ of all teen purchases are user-driven. Staff at both Libraries tended to differentiate between readers of graphic novels and other fiction readers, often anecdotally suggesting that male teens preferred graphic novels to other fiction. However, there was no suggestion that readers of graphic novels were being targeted in different ways to other readers..

Interviewees at Library A and Library B named computers and free internet as services that, although not designed specifically with teens in mind, have seen a large uptake by teens. Library A has also recently begun offering free wireless across all of its libraries; this was another service which had seen high uptake by teenagers.

Most staff at both Libraries also felt that one of the important services they offered teens was a simply a place that they could be, for socialising, studying, or other activities which did not necessarily involve using other library services. This, and services offered through Library websites, will be discussed further in Section 5.3.4. 
At Library B there are two annual organisation-wide programmes, both run during school holidays. The first is a reading programme, which teens opt in to and compete to win points by reading books, using databases and attending specific events run at their community libraries. While this is run in part to promote library services, it also provides an opportunity for Library B to encourage literacy and information literacy. "Every week we set a different database for them to look at, with five pretty simple questions, but just to give them the gist of how databases work, because we felt like we're paying for the databases, they're reliable, they could be using them for homework... So, it was passed off as fun, but it was more about literacy." The second programme is an art competition, which is more about simply engaging teens with the library rather than particular library services.

Library A does not run any similar organisation-wide programmes; this was explained anecdotally by one strategic staff member, who said that such a programme based on the one run at Library B, “didn't seem to actually work, so it wasn't worth the time it took to run." It did, however, see success at some individual community libraries, some of which continue to run teen reading programmes at a smaller, local level.

Information literacy classes are also run at community-level at Library A. Although these are run across various community libraries and are typically similar classes, they do have to be modified for individual communities: "The first digital photography learning thing 
that happened was [Suburb], so of course all the kids had their own, or the family's, so here we're actually providing the camera for them to use, and have a bash at."

The most common community-level product for teens across both Libraries is book clubs; those discussed in interviews operated on widely differing terms, with one including participants ranging from 12 to 22 , despite the "teen" label, while others stuck more closely to the more specifically teen market. Some focussed heavily on reading, encouraging members to talk about the books they had read, while others, despite calling themselves book clubs, centred more on social and arts activities. Staff at both Libraries tended to talk about their book clubs in more detail than other teen activities; however, some teen activities mentioned were job and movie clubs, author and other speaker visits, and gaming competitions. At the time of the interviews, Library A was trialling a Wii at one of the community libraries.

\subsubsection{Promotion}

The biggest immediate difference between Library A and B in terms of promotion is how promotional material is developed - Library A have their own in-house marketing team which includes a graphic designer, while Library B develop the concepts, then work with their district council's marketing team to produce the material. However, this variation does not extend into the way promotion is developed at the community library level, with community libraries at Library A and B both creating their own promotions for their own local events and services. One operational staff member at Library A described the marketing-created book club flyers as "unexciting ... it wasn't going to be riveting to the 
teens to want to pick it up and take it away" which suggests that community libraries' perceptions of their customer base differ from those held by marketing staff.

Strategic staff members at Library B were clear that cost is the biggest challenge when it comes to promotion. Both strategic and operational staff expressed regret that their budget does not currently allow them to send mass-texts to teens, as they believed that that would be one form of promotion that would get teens' attention. There was an overall emphasis at both libraries on low-cost promotional tools and techniques.

For example, staff at Library B discussed how trends in teenage popular culture are often essentially a form of free promotion for the library. The recent popularity of the Twilight series saw an increase in interest among teens to use their community libraries, although due to the restrictions placed on teen users - most importantly, the need for a parent or guardian to agree to their teen becoming a library member - this interest could not automatically turn into membership. Among teens who are already library members, staff talked about a definite tendency to read any books which have received a large amount of media attention, particularly those that had been made into films. This was also true of Library A, where staff also spoke about the negative impact of pop culture trends on libraries - the biggest once again being cost, where teen collection budgets were stretched to deal with the demand of teens for popular books, with waiting lists numbering into the hundreds. Relying too much on trends like Twilight also presented problems; one strategic staff member gave the example of using Twilight to promote a teen book club 
and missing the target market completely, with some of the responders being women in their mid to late twenties.

Community libraries perceive that using their relationships with teens is the best way to promote services and events - viral marketing, or word-of-mouth communication is used by everyone who interacts with patrons; one community library manager at Library B encourages teen library users to pass on library news to non-users with promotions like "bring a friend" type events. Teen librarians and library assistants who have particularly good relationships with teen patrons also email individual teen users to promote particular services, as opposed to the more formal bulk emailing that is used.

Library B's relationships with other community organizations such as youth groups and religious associations are also important for promotion. The one most commonly cited by staff is relationships with high schools; operational staff try to visit schools in order to talk to classes and assemblies about programmes and events run at or through community libraries. Again, financially this is a low-cost promotional technique, but it does depend on library staff having the time to execute it. It is also not feasible for every community library, as it depends on there being one or more local high schools with which to build relationships. This is particularly difficult for those libraries that are close to city boundaries - the nearest high schools may fall within a different district council, and be uninterested in forming links. "... about $90 \%$ of their kids [live in a different city], so they don't want me coming in to promote my library, because it only relates to a very small part of their school." 
Few staff members interviewed at Library A appear to have made connections with their local schools. One strategic staff member had found that such relationships were not easy to form, due to the degree of difficulty in making the first contact with individuals within a school, and the problem of retaining relationships when those individuals moved to another school or role.

Library B makes high use of their website for teens promotional purposes. A recent teen holiday programme saw a $24 \%$ increase of the use of their teen pages. However, staff members also acknowledge that many of their patrons do not have regular access to the internet, which means that promotional material such as posters are still used 'I'd love to say that we use a variety of modern technology, but truth be told a lot of our teenagers don't have computers in the home." Library A also concede that not everyone uses the internet, although their operational staff tended to see internet non-users as more elderly patrons unused to technology rather than a result of the digital divide.

As far as Web 2.0 goes, both libraries promote their services and events through Twitter. Library B seems to have been more successful in this approach, garnering more than three times as many followers as Library A, although it must be noted that Library A's Twitter was set up far more recently. Library B also has a Facebook page, while Library A has a number of blogs, including one aimed at teens. 
Again, an important aspect of teens marketing is capturing parents' interest and gaining their approval as well. Even though displays and posters are designed with teens in mind, it is often parents who enquire about services like the teen book clubs run at most community libraries and who encourage their children to attend.

\subsubsection{Price}

Overall, pricing has been used by both Libraries to encourage use of services and discourage certain patron behaviours. This includes overdue fees and use charges. In monetary terms, the majority of services provided at both Libraries are free for teens. Staff at both Libraries particularly notice the high rate of holds placed by teens, which is assumed to be because of the no cost policy for teens practiced by both Libraries - in contrast, adults, who are charged for placing holds, do so less often and place holds on fewer books.

Library B has recently removed overdue fines for teenagers. This is a strategy that has been aimed at parents and guardians, rather than at teenagers, as they are the guarantors of teen members and ultimately responsible for payment of fines and fees. This approach has been adopted with the goal of increasing membership by teens; once again this shows that parents - adults - do need to be considered in teen marketing rather than viewing teens as an isolated, independent group.

Library A has found a different solution to the same problem - while library membership for patrons under 18 usually requires an adult guarantor, librarians - usually community 
library managers - can at their own discretion allow teenaged patrons to sign up for a "minor card", which allows holders to borrow one item at a time without parent or guardian approval.

Services which are charged for at both libraries were typically not seen by staff as services which were often used by teens - these included borrowing CDs, DVDs and games. At Library B one operational staff member said that in her community library teens tended to watch or listen to these on available computers rather than borrow them, as they would not be charged for this. Another community library at Library B offers "vouchers" for audiovisual material as prizes and awards to teenagers and children, which allow them to borrow DVDs and other materials for free.

Library B has also been using price as a disincentive to visiting certain internet sites: "If you want access to...Bebo, it's a dollar for half an hour to two dollars for an hour. Other social networking sites like Facebook are free. Initially when Bebo came out it was used to organise fights and things like that at the high schools, so police liaised with [Library $B] . "$ It was indicated that this policy is soon to change, to allow all social network sites to have no charge.

Staff at both Libraries gave very similar answers on the subject of what teens give up to use the library. "All library use is an opportunity cost, you're using the library or being on the library website rather than doing something else...Time would be one thing. I 
was trying to come up with a very clever answer around reputation and image, but I think that's just imposing multiple layers of stereotypes."

While "time" was most commonly identified, most interviewees also gave a range of possible answers for what they might be using that time for - spending time with friends or on school work; at extra-curricular school activities or outside school activities, such as sport; watching TV. Several staff members across both Libraries felt that teens did not have to give up anything in order to use the library; in these cases, the staff members believed that activities that teens might have been involved in outside of the library, such as socialising with friends and study or homework time were simply taking place at the library instead of elsewhere. Staff who were involved in organising regular events, such as book clubs, generally tried to hold them on alternating days, in order to allow teens with other regular after-school events, such as practices, to attend some of the time.

There was a feeling among some of the interviewees at Library B that some teens, usually in specific areas, did not have much else to give up, as outside of the library there were not that many activities or places available for them. "There's nowhere free within easy distance, whether walking or bus or after school, that they can go and hang out and they can be safe and warm and no one expects them to buy anything."

One less evident form of cost was touched on earlier by a strategic staff member at Library A, who mentioned reputation, and that is identity. Although, like the previous interviewee, most librarians were unwilling to judge whether or not libraries are places 
that are "uncool", and which teens become less "cool" for visiting, some staff felt more strongly that the need for parental approval meant many teens had to give up their sense of independence to join the library. "There's giving up a little bit of pride in order to get their parents to come in."

\subsubsection{Place}

"But teens and tweens use it almost like a community space, they come to hang out, hang with their friends, it's not so much about coming and getting a book ... I think they use it as a meeting place and as a hung out just as much as for its resources”

As mentioned in Section 5.3.1, staff at both Libraries cite using the library as a "hang-out space", or a place for socialising, as one of the top uses of libraries by teens. Because the literature conflates place as a product with place as part of the marketing mix, both will be dealt with in this section.

Situation was repeatedly cited as being an important part of place - both the library's location relative to other parts and places of the community, and where the teen area is situated within the library itself. For the library's placement, proximity to high schools is clearly an important part of being able to connect with community libraries, as those staff members with nearby high schools spoke about the library being used after school by students from specific, close by secondary schools. One community library operational staff member at Library B with no high schools in close proximity spoke about the difficulties of trying to attract in teens - "They're not getting back into our area until 
4.30, and the library closes at $5 o^{\prime}$ 'clock. What I saw was that there was that there was no opportunity for our kids to use the library." However, libraries that do not see much teen usage during the week do have teenagers visiting during the weekends. At Library A, one library situated in the business district with specialised research facilities sees not only local teens, but "secondary school students from everywhere on the weekends doing homework, doing their research project."

All interviewees came from individual libraries in which there were specific areas for teens; these areas were usually signposted by their positioning next to the teen collections. There were some trends in what library staff thought was and was not appealing to teens in the positioning of a teen area in a library. One common idea was that "they don't actually want to be right in front of the library staff, and that they don't actually want to be close to the kids' area ... they're wanting to differentiate themselves." In several libraries, use of the teen space by other patrons like children or adults meant that teens were themselves reluctant to use the area.

Staff at libraries where teen areas had not been successful were able to point out other areas that teens had adopted as their own space; this varied depending on the space available in each library. One community library at Library B has a mezzanine floor which is accepted as being the area used by teens for more social purposes, as their allotted area, near the teen fiction, has few chairs, and those it has are frequently used by adult readers. The library's "peaceful area" also gets used by high school students during exam times - "it's meant to be a quiet area with no food, no talking, but during exam 
time we try and turn a bit of a blind eye unless someone is doing something really inappropriate."

Many interviewees discussed the look and furnishing of a teens' space as well. Staff tended to think that different libraries needed different elements in order to create a space that suited their own teens - taking the example of beanbags, one operational staff member at Library B explained that "[beanbags have] been really popular, we've trialled bean bags in other areas and it hasn't worked in terms of, they get vandalised really easily so you need something that's a bit more robust" while a community library at Library A found that teens would not use bean bags as they were favoured by the local vagrant population.

While at Library B all staff interviewed felt that spaces set aside or designed especially for teens were important, at Library A opinions were more diverse. While all of the staff with an operational role were positive about teen spaces, several of the strategic staff expressed concern that teen spaces were being created needlessly. One interviewee suggested an alternative approach, "it's not about a particular kind of person comes in and reads here, a particular type of person goes there, anyone who might enjoy reading teen writing, anyone can just go and use that teen material and sit down near it and read it," although this was tempered by a colleague who felt that before introducing any changes, teens themselves would need to be consulted - "[we need to] start talking to that age range and saying, what do you want? Not what we think you want, but what do you want? And it might be quite different from what we have in our heads." 
Library A and Library B have significantly different approaches to teens on their websites. Library B has a very obvious link to a teen section on their front page; the section contains further links to information on new lending material, recommended reading lists, reviews and upcoming events, study-related resources organised by subject area and career-related resources. As well as participating through social networking sites like Twitter and Facebook, teens are able to engage with Library B through their website, with a feedback page. The website is highly used; one comment given was that "some teens - do a lot of online stuff, sometimes their main branch is our website, rather than actually coming in."

In contrast Library A does not have a central online resource for teens. Teen pages are found under general headings, so that, to take the teen blog for example, its link is not found on a page which links to all the teen resources, but on a page which links to all of the Library's blogs. Many staff members expressed dissatisfaction with the website. However, the Library is still attempting to engage with teens through the teen blog, and it does have many of the same facilities as Library B.

\section{$\underline{5.4 \text { Evaluation }}$}

At both Libraries, measuring marketing success means counting numbers - the number of participants at special events, the number of hits on the websites, and circulation statistics. Both Libraries have the ability to look at the lending statistics for the teen collection, but not the ability to single out the statistics for teen patrons. This obviously 
means there are limitations on how well teens' library use can be judged in this way - not all teen collection users are teens, and teens do not only borrow books from the teen collection. There are other problems with this method, too - some community libraries see low circulation, but low circulation does not necessarily mean that resources are not being used - "Books are read in the library, there's a mess at the end of every day".

Feedback from patrons happens formally and informally at both Libraries, with patrons able to communicate directly with library staff or through channels such as written and online feedback forms. Both Libraries conduct semi-regular customer surveys; unfortunately, because most teens are minors, this often makes them ineligible to take part.

Neither library appeared to have a formal process for reviewing marketing campaigns in terms of the Four P's. The implications of this will be discussed in the following section.

\section{Findings}

The findings show some correlation between marketing theory and the marketing to teens practised at Library A and Library B. However, much of the marketing occurring at both libraries was organic and informal, rather than structured and formal.

Consumer targeting in particular seemed to be more organic than planned. While there was some obvious and purposive segmenting in the Libraries' collections, with children's and teens' collections segregated, and with specific and different rules and policies for 
children and teen users, the other most common form of segmentation, socio-economic segmentation, a by-product of the location of the community libraries, appeared to be more unintentional. Although it does seem unlikely that any of the community libraries were built without the size and demographics of their communities being taken into consideration, these buildings are seldom relocated, which means that as the community demographics change, the libraries must target the new demographics; the libraries are in this way naturally passive in choosing which segment of the region's population to target.

While the interviewed staff were willing to suggest different groups that used their libraries, there was little consensus over who these same groups were, and even the terminology used to refer to the groups differed - for example, elderly and senior citizens were both used to describe older patrons. Groups that were already being particularly targeted by the Libraries, such as mothers and babies, were commonly identified, suggesting that marketing campaigns may make staff more aware of particular market segments.

There was little consistency between interviewees in defining patron groups. As discussed in Section 5.2.1, even though both Libraries defined teens as young people aged between 13 and 18, staff themselves did not all define teens as that same age group. Most felt that teens did fall within this 'high school' age range, but there were exceptions, such as the 'tween' age, 11 and 12 year olds who some interviewees felt straddled the gap between childhood and teenhood. There were also older patrons who wanted to continue using teen services once they became adults, as they felt attached to them or found no 
equivalent opportunities for adults. In addition, a small number of interviewees, reiterated the idea already found in the literature, that within the label of "teen" there are differences between older and younger teenagers. However, exactly what these differences are was not well articulated, aside from some idea that older teens are more mature, and may already have left school and be working.

The services themselves reflected this range of definitions - the same or a similar teen service provided at different community libraries often involved different age ranges at the different branches. This is not a negative effect as such; in fact, it could suggest that in the different libraries teens have different needs, relating to their different lifestyles, and that community librarians have recognised this. What could not be determined was if this then conflicts with the organisation-wide teen services which have a different, specific age range.

A further problem with the patron segments suggested by interviewees, was that these often revolved around products used by the patrons, rather than defining the patrons themselves. This runs counter to consumer targeting theory, wherein the population is segmented into groups based on demographics and lifestyle, and the marketing mix is built around a segment's or segments' perceived needs or wants. Segmenting library patrons by the services they use appears to run counter to this idea, unless users of a particular service all share the same or similar characteristics. Furthermore, it suggests that library patrons using one service are not using any others, which may be true in some cases, but is unlikely to be true in all cases. 
There was a resistance among library staff to segment patrons in more than one aspect at a time. So, while able to refer to a single age group, none of the interviewees could split the age groups further, by gender, ethnicity or other demographic variables. Many library staff emphasized the need for events to appeal to all teens. However, the potential consequences of this approach were apparent, with one operational staff member who had tried to make their book club appeal to a wide range of their library's teens finding that the club did not work out - "the ones that are avid readers do not want to come to a book club to talk about how they've found a book. They don't like the social aspect of it, especially when they're mixed with non-readers. The non-readers, they just go there for free food and a good time." Either the club needed to have a finer focus in terms of which teens it was intended to appeal to - like the more successful book clubs at other libraries - or, another product with a wider appeal should have been chosen.

These problems do not show an inability to segment markets as much as inconsistent consumer targeting throughout the Libraries. Without having an overarching strategy for teens for reference, staff are left to create their own definitions and strategies in an ad hoc approach.

While Section 5.3 shows that both Libraries make use of a range of methods in each aspect of marketing's four P's, it is important to bear in mind that these categories are not meant to be considered individually, but as parts of an interrelated whole - that is, for 
each product, its price, place and promotion should be considered. However, for ease of analysis in this report, the four P's are being considered separately.

It was difficult to ascertain how the Libraries identified new products for the teen market. Most interviewees mentioned gaining inspiration from other libraries, or library blogs, rather than conceiving their own ideas. There were also mixed results in adapting products "borrowed" from other institutions, such as the network-wide reading programme that Library A tried and failed to implement successfully. There was some innovation in the Libraries' traditional services, such as the user-driven purchasing that has evolved, particularly at Library B.

There is some question as to whether library staff themselves understood the full range of services that they were offering; some focused particularly on one product, such as the teen fiction collection or the Library's website; one operational staff member identified different groups of library users solely on the types of books they read, with no regard for other services. While this could simply reflect those staff members' own responsibilities or interests there is the potential that by having this narrow focus, they are themselves unlikely or unwilling to acknowledge other products that are available to teens. In libraries where only one staff member had the particular role of liaising with teens, this has the potential to be particularly problematic.

While much of the related literature focuses on marketing the library as a whole, rather than the library's individual products, both Libraries are marketing a range of their teen 
services. The marketing of some products, such as events and clubs, is more obvious as they are promoted through visual media such as displays and posters, but by offering teens the ability to suggest books for the teen collection and encouraging use by lowering fees and fines for teens, the Libraries are attracting patrons to one of their core services.

In terms of developing or choosing what products to provide, clearly this is for the most part a formal process. Both network-wide and community level services are provided after much discussion and planning and appear to be selected for their ability to fill teens' perceived needs. There is an organic element to them in that sometimes after being introduced the services grow ("[my manager] was talking about the teen book club at [library], where she used to work, and she sort of suggested that I start one.... And it's turned out to be a much bigger part of what I do than I had anticipated - in a really good way.") or develop into something else. The computer facilities provided at the Libraries free, limited computer use at both, and free wireless at one - are a particularly interesting example. Although these facilities were introduced in a formal, structured manner, they saw a much larger uptake by teens than was expected, and as a result different community libraries have had to adapt their own rules and methods of use by teens - a more organic process.

Both Libraries seem to have a strong understanding of the concept of promotion, although knowledge of the available ways of promotion differed considerably among staff. Significantly, almost all staff felt that word-of-mouth promotion was still the most important; this suggests that library staff have strong relationships with teen patrons, and 
value those relationships, but it also means that the more formal channels of promotion are seen as less important. Given that other forms of promotion tend to be more costly in financial terms, this may be something that needs further investigation - are staff not confident in other forms of promotion, or is viral marketing simply a more effective promotional tool for teenagers? Notably, when interviewees talked about parents enquiring into teen-specific services and activities, they often mentioned that it was parents who had seen library displays. This may suggest that although aimed at teens, the displays are missing their mark - although by attracting parents, they clearly are not without merit.

Library B also did not seem to have any policy related to promotion - presumably, any promotional idea would be run past a manager or relevant staff member first, but this was not mentioned by any interviewee. Library A has a more structured policy, with posters, bookmarks and other material sent to their marketing department to be approved before it is launched to the public.

One major flaw in the promotional tools used at both Libraries is that almost all of them require teens to "opt-in", or decide to receive the promotion. This is most obvious in terms of the teen e-newsletters that Library A produces; patrons have to sign up for them on the Library's website in order to receive them. This is also true for Web 2.0 websites like Facebook and Twitter. To a lesser extent, this is due to the fact that a lot of promotional material such as posters and brochures are always displayed inside the library, but not necessarily elsewhere in the community, and that in order to view the 
products being promoted on the website, teens have to first actually visit the website; this means that services are seldom promoted to non-users. There are some exceptions to this - Library B has used radio advertisements for one of its community libraries, and Library A has used bus-stop billboards - but neither of these are standard methods for either Library.

The most common exception to this internal focus on promotion is community librarians and library assistants who go into high schools to promote library services in assemblies and classes. This is interesting, as, like viral marketing, it is promotion that tends to be done on a less formal basis - while it involves liaising with school staff, usually teachers, this is generally done on a person-to-person level, rather than organisation-toorganisation. While this can lead to strong links between library and school, it also means that if either librarian or teacher leaves their organisation, the relationship essentially needs to be rebuilt.

Both Libraries show a good understanding that the costs involved in using teen library services may not just be financial, and Library B obviously recognises that even minimal financial costs can be a burden to some patrons. The opportunity costs identified showed that staff had a limited idea of what teens enjoyed outside of the library - social time and study time were most often mentioned as what teens might be forgoing to use the library, but what these social activities might be were not specified, beyond "hanging out with friends". 
However, both Libraries also can be seen to be trying to minimize both financial and opportunity costs, for example, working with teens to find times and dates that suited them for special and regular events. Reducing patrons' financial costs is more difficult, as it can mean that the Libraries have to absorb those costs themselves - whether it is the cost of lost books written off under the "minor card" system, or the smaller costs of transport involved in moving books between community libraries to satisfy free holds and requests.

At some community libraries, staff felt that there were few costs for teens using the library; these tended to be in lower socio-economic communities, where there were few other activities available for teens. In contrast, one interviewee from a library that was situated in close proximity to a mall felt that the library had to compete with the other facilities in the mall to attract teens' attention; the fact that library services cost a lot less than a trip to the cinema did not necessarily sway teens' preferences. This emphasises that price can not be considered alone when marketing to teens.

One recurring comment that came from the interviewed staff was that teens may be giving up something else in order to use library services - their sense of independence. This highlights a theme that ran through many of the interviews - that teens can not be marketed to in a vacuum; their parents are an important part of the equation, too. As previously mentioned, this includes noticing displays and authorising teens' library membership, but parents may also still have a role in monitoring and allowing teens' library visits, their choice in reading material, and their participation in library events. 
There was not a "one size fits all" approach by parents, either: interviewees felt that some parents were willing to leave their teens alone all day in their community library, while at the other extreme there were parents who wanted to be heavily involved in their teens' library use. This variation held for teens as well - some did not want to involve their parents at all, while others were willing to share their library experiences with their parents. Despite the fact that many of the interviewed staff had noticed the role parents played in teens' relationships with libraries, this does not seem to be captured in any formal way in the marketing at either Library. Marketing is still very much aimed only at teens.

Library B clearly sees that 'place' refers to the virtual world as well as the library's physical buildings, with a website set up to direct teens straight to pages and sites that will benefit them, and making themselves accessible through Facebook and Twitter. Library B also evidently agrees with the literature which suggests the need for a teen space in the library to "tell older teens that they are welcome in the library and even encouraged to stay" (Alessio, 2004, p. 87). Library A presents a more complex picture. While, like Library B, Library A has designated teen areas in all its libraries, there was a trend among strategic staff to question whether this practice is necessary, although there was no suggestion of changing the status quo without any research or consultation with teens. Library A's website already seems to be experimenting with this theory, with no one specific area for teens to access teen-focused resources. 
At both Libraries, in libraries where teens had no area, or were unhappy with the area they had been given, they had adopted a different area for their own use; in some cases they had adopted several areas for different purposes - one for socialising, for example, and one for studying. It should be noted that while staff did not necessarily feel that areas for studying were any quieter than areas for socialising, the fact that the teens themselves marked them as having different purposes is significant. It could be that simply having "a teen area" is not enough, and that several areas are needed; or, as suggested by one strategic staff member, that having a "teen area" is unnecessary, and there should instead be places for all patrons to go when they want to do a specific activity. However, as some interviewees suggested that teens rejected formal teens' spaces if they were shared by other age groups, this is clearly a topic that needs further investigation.

There is obviously some ongoing evaluation of the marketing mix at both Libraries - reevaluating pricing is an example of this, as is adopting new technologies for promotion and rethinking the role of place for teens. What is less obvious is how this evaluation happens. Use of library services is generally measured quantitatively, and there are limits on these forms of measuring - for instance, there are library door-counts to see how many people come into the library, but it is not possible to find out those patrons' demographics just by counting. As mentioned previously, library surveys are conducted at both Libraries, but teens do not always participate in these; and some interviewees mentioned that they had found teens reluctant to respond to such surveys in writing. One of the community libraries at Library B has started recording teens' verbal responses to events, 
but this is a new initiative and its usefulness and viability on a wider scale has not yet been ascertained.

With neither Library currently having a marketing strategy in place for teens, marketing would appear to be more tactical than strategic - teen marketing being developed on a case-by-case basis rather than in compliance with an over-arching strategic plan. Certainly at a community level, marketing for specific products is carried out by the librarians or library assistants who have designed or are interested in promoting that product. While community library managers and the Libraries' marketing department or associates may have final say, this kind of marketing is driven in a bottom-up manner, and given that all operational staff respondents had no formal marketing knowledge and did not know any details of their Library's marketing strategy, it is obvious that the marketing of community-level products is conducted in a tactical manner, with marketing theory only influencing marketing at a late stage, if at all.

This is not to say that without formal marketing knowledge, these products are being consistently poorly or unsuccessfully marketed. Because of their close relationship with patrons, operational staff are able to talk directly and informally with teens, to find out what they need and want and what appeals to them. Community library staff also hold a good deal of institutional knowledge, and know what has been trialled in the past, and how teens reacted to that - there are even instances of this knowledge trumping the suggestions of those with a marketing role within the organisation: "So sometimes you get marketing type people saying, we should do this, and you're like, uh, no. Not going to 
work. Maybe it will work for that group, but not this one." Nor does this lack result in a lack of innovation in community-level marketing, with staff taking to Web 2.0 technologies like blogs, and discussing the possibilities of texting, for promotional purposes. Unfortunately, this does place the onus on individual staff members - if they leave, or change roles, their knowledge is likely to be lost as there does not seem to be any mechanisms in place to retain it.

Without a teen marketing strategy and with minimal marketing training among most operational staff members, Libraries are relying heavily on the passion and library experience of these staff to make up for it. At best, this produces mixed results. To take again the example of the various book clubs run across the Libraries, there were many that had been established successfully, but two stuck out as suffering as a result of poor marketing; one, mentioned previously in this section, as the result of poor market segmentation, while the other, discussed in Section 5.3.2 focused too heavily on Twilight and missed its intended market altogether.

For organisation-wide products, marketing theory plays more of a role, as for these products staff tend to work directly with the relevant marketing arm early in the development stage. But even this top-down, more formal approach to developing marketing plans still has a somewhat organic component; the restrictions on dealing with teenagers without parental consent mean that the library staff involved rely on their own teen contacts, or the opinions of other staff who have teen contacts, rather than talking formally with teens to test the marketing plans. The restrictions and difficulties in 
evaluating marketing plans also hinders the ability to improve on what has been done before, leading to a somewhat haphazard approach to developing new marketing ideas.

\section{Conclusions}

The New Zealand public libraries sampled aspire to attract teenagers to use their services but do not use strategic top-down marketing methodologies to pursue this objective. Existing marketing projects tend to be point solutions which are not interconnected in a coherent whole. Both Libraries surveyed had marketing champions at either strategic or operational levels, or both, but the Libraries had in one case not yet formally recognised the need to develop strategic marketing plans for teens, and in the other case had recognised the need but was yet to start. Library marketing is, therefore, predominantly organic and informal. Tactics are developed or copied from other libraries by individuals who have a particular interest in the teen segment of the market. The Libraries' marketing tactics typically do reflect some elements of marketing theory, but no instance was identified in this survey where the whole theory was brought to bear.

This research did identify several areas that need further investigation. The first is the impact of parents and guardians on the relationship between libraries and teens, and the influence that they have on teen marketing. Many interviewees identified parental permission and authority as a key factor in the design of library products and policy, and parents were also reported to play a role in the promotion of services, yet parents are seldom mentioned in the literature on libraries' teen marketing. 
Secondly is the role of price - in financial terms - in the marketing mix for teens. Both Libraries identified overdue fines and lost book costs as being a barrier for potential teen patrons, but at the same time it was suggested that there were teens who preferred more expensive activities such as movie-going to visiting the library. It is unclear whether this apparent disparity is a case of patron expectations or different teens having different priorities, or whether there is some other explanation.

Lastly, for financial reasons, library teen promotion tends to be to a closed group of existing library users. Given that both Libraries use viral marketing extensively, and have both begun to exploit Web 2.0 technologies, there is an opportunity to explore how these low-cost promotional techniques may be used to attract non-users.

Libraries' marketing has clearly moved on from the time when marketing was badly understood and viewed negatively as a commercial construct, but it has not yet matured to being fully integrated across library networks. On balance, libraries are to be commended for their teen marketing programmes, but it should be recognised that significant improvement in outcomes should result from more systemic and strategic development of teen marketing strategies. 


\section{Bibliography}

Agosto, D. E., Paone, K. L., \& Ipock, G. S. (2007). The female-friendly public library: Gender differences in adolescents' uses and perceptions of U.S. public libraries. Library Trends, 56(2), 387-401. doi:10.1353/lib.2008.0000

Aharony, N. (2009). Librarians' attitudes towards marketing library services. Journal of Librarianship and Information Science, 41(1), 39-50. doi: $10.1177 / 0961000608096717$

Alessio, A. (2004). Respect for the future: Making space for older teens. In S. B. Andersen (Ed.), Serving older teens (pp. 87-104). Westport, CT: Libraries Unlimited.

Andersen, S. B. (2004). On the verge of adulthood: Older teens and the library. In S. B. Andersen (Ed.), Serving older teens (pp. 1-26). Westport, CT: Libraries Unlimited.

Andersen, S. B. (2007). Childhood left behind : 'tweens, young teens, and the library. In S. B. Andersen (Ed.), Serving young teens and 'tweens. Westport, CT: Libraries Unlimited.

Association of Public Library Managers Inc. (2010). Our member libraries. Retrieved from http://www.publiclibrariesofnewzealand.org.nz/about/our-member-libraries

Baldock, C. (1993). Marketing libraries: A survival guide? Library Management, 14(1), 4-8. doi:10.1108/EUM0000000000843

Bolan, K., Canada, M., \& Cullin, R. (2007). Web, Library and Teen Services 2.0. Young Adult Library Services, 5(2), 40-43.

Booms, B. H., \& Bitner, M. J. (1981). Marketing strategies and organisational structures for service firms. In J. Donelly \& W. R. George (Eds.), Marketing of services (pp. 47-51). Chicago: American Marketing Association.

Bourke, C. (2007). Public libraries: Partnership, funding and relevance. Australasian Public Libraries and Information Services, 20(3), 135-139.

Braun, L. W. (2009). Using technology to market teen library programs and services: Is a website the answer? Voice of Youth Advocates, 31(6), 510-511.

Bryman, A. (2008). Social research methods (3rd ed.). New York: Oxford University Press.

Carpenter, J. S., \& Caton, C. A. (2008). Booktalking: wicked cool advertising for your library. In C. Smallwood (Ed.), Thinking outside the book: Essays for innovative librarians (pp. 107-109). Jefferson, NC: McFarland \& Co. 
Chamberlain, A., Chamberlain, G., \& Cabral, J. (2007). Public Libraries. In A. Fields, R. Young, \& Open Polytechnic of New Zealand (Eds.), Informing New Zealand: libraries, archives and records = Hei puna whakamohio mo Aotearoa $:$ whare pukapuka, puranga korero, whare taonga (5th ed., pp. v.). Lower Hutt, New Zealand: Open Polytechnic of New Zealand.

Chew, C. (2007). Branding in New Zealand public libraries: An evaluation of their brand strategies (Unpublished masters research paper) Victoria University fo Wellington, Wellington, NZ.

Clayton, K. A. (2007). Marketing of public library web pages (Unpublished masters research paper) Victoria University of Wellington, Wellington, NZ.

Coleman, P. (1984). Public libraries can and do make a difference: A case to be proved. European Journal of Marketing, 18(2), 56-64. doi:10.1108/EUM0000000004769

Cook, S. J., Parker, R. S., \& Pettijohn, C. E. (2005). The public library: An early teen's perspective. Public Libraries, 44(3), 157-161.

Corradini, E. (2006). Teenagers analyse their public library. New Library World, 107(11/12), 481-498. doi:10.1108/03074800610713307

de Saez, E. E. (2002). Marketing concepts for libraries and information services (2nd ed.). London: Facet Publishing.

Delgado-Gomez. (2002). Young adults and virtual libraries: A case study. New Library World, 103(7/8), 277-283. doi:10.1108/03074800210438163

Dimick, B. (1995). Marketing youth services. Library Trends, 43(3), 463-477.

Doherty, N. F., Saker, J., \& Smith, I. G. (1995). Marketing development in the public library sector: An empirical analysis. Journal of Information Science, 21(6), 449458. doi:10.1177/016555159502100604

Doherty, N. F., Saker, J., \& Smith, I. G. (1998). Developing 'appropriate' marketing within the public leisure and library sectors: A comparative study. Managing Leisure, 3(3), 149-161.

Doyle, M. (2008). Go where the teens are. Voice of Youth Advocates, 30(6), 504-505.

Dubicki, E. (2007). Basic marketing and promotion concepts. The Serials Librarian, 53(3), 5-15. doi:10.1300/J123v53n03_02

Fagan, J. C. (2009). Marketing the virtual library. Computers in Libraries, 29(7), 25-30. 
Harrison, P. J., \& Shaw, R. N. (2004). Intra-organisational marketing culture and market orientation: A case study of the implementation of the marketing concept in a public library. Library Management, 25(8/9), 391-398.

doi:10.1108/01435120410562899

Hood, D., \& Henderson, K. (2005). Branding in the United Kingdom public library service. New Library World, 106(1/2), 16-28. doi:10.1108/03074800510575320

Jones, P. (2002). New directions for serving young adults means building more than our collections. Journal of Youth Services in Libraries, 15(3), 21-23.

Kern, M. K. (2009). Virtual reference best practices: Tailoring services to your library. Chicago: American Library Association.

Kinnell, M., \& MacDougall, J. (1992). Marketing public library services - opportunities for change. Library Management, 13(4), 22-32. doi:10.1108/01435129210016609

Kotler, P., Brown, L., Adam, S., Burton, S., \& Armstrong, G. (2006). Marketing (7th ed.). Frenchs Forest, NSW: Pearson Education Australia.

Mahood, K. (2004). Off the page and onto the stage: Booktalking to older teens. In S. B. Andersen (Ed.), Serving older teens (pp. 161-164). Westport, CT: Libraries Unlimited.

Mi, J., \& Nesta, F. (2006). Marketing library services to the Net Generation. Library Management, 27(6/7), 411-422. doi:10.1108/01435120610702404

Nkanga, N. A. (2002). Marketing information services in Botswana: An exploratory study of selected information providing institutions in Gaborone. Library Management, 23(6/7), 302-313. doi:10.1108/01435120210432273

Owen, C. (1998). What do teenagers really want? : investigating both sides of young adult services (Unpublished masters research paper) Victoria University of Wellington, Wellington, New Zealand.

Owens, I. (2003a). Introduction. In I. Owens (Ed.), Strategic Marketing in Library and Information Science (pp. 1-5). Binghamton, NY: Haworth Information Press.

Owens, I. (2003b). Marketing in library and information science : a selected review of related literature. In I. Owens (Ed.), Strategic marketing in library and information science (pp. 5-32). Binghamton, NY: Haworth Information Press.

Rossiter, N. (2008). Marketing the best deal in town: Your library: Where is your purple owl? Oxford: Chandos. 
Rowe, J. L. A. (2002). The design of public library facilities for young people (Unpublished masters research paper) Victoria University of Wellington, Wellington, NZ.

Roy, L. (2003). Marketing in public libraries. In I. Owens (Ed.), Strategic marketing in library and information science (pp. 215-235). Binghamton, NY: Haworth Information Press.

Ruhlmann, E. (2010). Libraries, hospitals join forces to promote wellness in body and mind. American Libraries, 41(4), 14.

Shontz, M. L., Parker, J. C., \& Parker, R. (2004). What do librarians think about marketing? A survey of public librarians' attitudes toward the marketing of library services. The Library Quarterly, 74(1), 63-84. doi:10.1086/380854

Smith, G., \& Saker, J. (1992). Developing marketing strategy in the not-for-profit sector. Library Management, 13(4), 6-21. doi:10.1108/01435129210016618

Snowball, C. (2007). Researching graphic novels and their teenage readers. LIBRES, 17(1). Retrieved from http://libres.curtin.edu.au/

Snowball, C. (2008). Enticing teenagers into the library. Library Review, 57(1), 25-35. doi:10.1108/00242530810845035

Sutherland, S. (2002). Passion, practice, partnership and politics: marketing the future of public libraries. Australasian Public Libraries and Information Services, 15(2), 61-69.

Tyle, A. (2008). Attracting high school students. In C. Smallwood (Ed.), Thinking outside the book: Essays for innovative librarians. Jefferson, NC: McFarland \& Co.

Van Slyck, A. A. (2001). The librarian and the library: Why place matters. Libraries \& Culture, 36(4), 518-524. doi:10.1353/lac.2001.0073

Walter, V. A., \& Meyers, E. (2003). Teens \& libraries: Getting it right. Chicago: American Library Association.

Walters, S. (2004). Library marketing that works. New York: Neal-Schuman Publishers.

Weingand, D. E. (1999). Marketing/planning library and information services. Englewood, CO: Libraries Unlimited.

Yin, R. K. (1994). Case study research: Design and methods. n. p.: Thousand Oaks Sage. 


\section{Appendix A}

\section{Public libraries marketing to teens: a study of two New Zealand libraries Information sheet}

Dear

My name is Helen Biggs, and I am currently studying for a Master of Library and Information Studies at Victoria University of Wellington. As part of the course, I am conducting research into how public libraries market to teens. Specifically, I am interested in discovering to what extent marketing theory is used. In order to carry out this research I will be interviewing staff at two public libraries, including yours. Victoria University requires that ethical approval be given for this research to go forward and this has been given.

I am hoping that you will agree to participate in an interview, in order for me to use the information you provide in my research. Names of staff and of your organisation will be suppressed in the final report, although due to the small sample size there is still the possibility that others may be able to contribute comments to individual participants. Interviews are expected to take no longer than an hour, and will be conducted by me in person.

You will have the right to check my notes taken during your interview, and will be able to see them later at your request. You will also have the right to withdraw from the research project up until 10 August, 2010. If you choose to withdraw before that date, any information you have provided will be destroyed and will not be used in the final report. If you do not withdraw, your information will be kept in a secure location for two years, and then destroyed.

Upon completion of the research project, a summary of the findings from each participating library will be provided to participants from the relevant libraries. A physical copy of the project itself will be held in the Victoria University of Wellington, as well as a digital copy in the university's Research Archive. Any further use of the information you have provided, will not go forward without your expressed, written permission. This includes using it in future publications such as articles and conference papers.

Please find attached a brief consent form for you to sign, should you choose to take part in this research.

Kind Regards,

Helen Biggs

BA BCom (Otago)

Phone: 021717497

Email: biggshele@myvuw.ac.nz

Supervisor: Dr Philip Calvert

Email: philip.calvert@vuw.ac.nz 


\section{Appendix B}

\section{Public libraries marketing to teens: a study of two New Zealand libraries Information sheet}

$\square$ I have been provided with adequate information relating to the nature and objectives of this research project.

$\square$ I have understood that information and have been given the opportunity to seek further clarification of explanations.

$\square$ I understand that I may withdraw from this study at any time before 10 August, 2010 without providing reasons.

$\square$ I understand that if I withdraw from the project, any data I have provided will be destroyed.

$\square$ I understand that any information or opinions I provide will be kept confidential, and will be reported only in a non-attributable manner.

$\square$ I understand that the information I have provided will only be used for this research project, and that any further use (including in publications such as articles and conference papers) will require my written consent.

I understand that when this research has been completed, the information obtained will be retained for two years, and then destroyed.

I consent to being interviewed. 


\section{Appendix C - Emails}

\section{Emails sent to Head Librarians \\ Email i}

Dear

My name is Helen Biggs, and I'm a Masters in Library and Information Studies student at Victoria University of Wellington (VUW). I have completed the classroom component of the course part-time over the past two years while working part-time in the Unitec Library in Auckland.

I am currently planning and negotiating the research component of the degree with my supervisor, and the purpose of this letter is to determine (in principle) whether you might allow me to interview some members of staff in your library to collect the information I require for this project. If I gain sufficient informal agreement to this, and my topic is approved by VUW, I will approach you more formally later in the year. By that stage I will know how many staff members I would like to interview, and the approximate duration of an interview.

My area of research is the use of Marketing by Public Libraries, with a particular focus on teenagers.

My supervisor for this project is Dr Philip Calvert. He can be contacted on (04) 463 6629, or at philip.calvert@vuw.ac.nz .

l'd be grateful for an early indication of your willingness to accommodate me in this matter.

Yours Faithfully,

Helen Biggs - BA, BCom (Otago)

\section{Email ii}

Dear

Following my email of April 7 (copied below) seeking informal support for your library's participation in my research for my Masters of Library and Information Studies, and your positive response to this, I'm now pleased to advise that my proposed topic, methodology and interview guidelines have been approved by my supervisor and VUW's ethics committee. I hope you are still in a position to support this study.

Ideally, I would like to interview between seven and ten managers and staff members from your library. Also ideally, participants would range from senior management through any managers with responsibility for marketing activities, 
managers with responsibilities for teen-oriented departments to staff who deal with teen library users on a day-to-day basis. I would be very grateful for your advice and assistance in identifying your personnel who would best fit these requirements. I would be happy to meet with you, discuss this on the phone or receive your suggestions by email - whichever is most convenient for you.

I plan to conduct these interviews in July, at mutually convenient times.

I attach for your information, the information sheet and consent form that will be given to each participant - please advise if you have any concerns regarding either of these.

Thank you once again for your support.

Helen Biggs 
Word count: 14,350 